\title{
Reconstruction of Anthropogenic Impact Intensity Changes during Last 300 Years in Lake Engure Using Analysis of Sedimentary Records
}

\author{
Maris Klavins ${ }^{1}$, Ilga Kokorite ${ }^{2}$, Maruta Jankevica ${ }^{3}$, Valerijs Rodinovs ${ }^{4}$, Liga Dreijalte ${ }^{5}{ }^{1-5}$ University of Latvia
}

\begin{abstract}
Environmental pollution with trace elements is considered as one of the most important environmental problems. Analysis of trace element accumulation in sedimentary phases of lakes may reflect the overall regional pollution level, but analysis of trace element accumulation patterns in sediment profiles can help to reconstruct the history of anthropogenic impacts. The aim of this study was to analyse trace element concentrations in the sediments of Lake Engure in Latvia and analyze factors influencing their availability. The metal concentrations in sediments of Lake Engure are at background levels, especially in comparison to metal concentrations in West European countries. However, analysis of element concentration changes in sedimentary profiles gives information about trends of recent accumulation (within the last 300 years) and the balance between natural and human induced accumulation processes.
\end{abstract}

Keywords - Lake sediments, organic matter, trace and major elements

\section{INTRODUCTION}

Studies of lake sediment composition can provide valuable information about the lake development character and thus can be used to study long-term, natural, human and climate impacts on lakes and their basins [1]. Coastal lakes are shallow water basins where sedimentary records contain proofs on nature, climate and human activities in the past [2]. Results of the lake sediment investigation reveal the character and changes of the environment during the lake development [3]. Likewise, lake sediments can be used to study periods of forest fires, climate-induced changes in vegetation, and human-induced changes to organic matter inputs and primary producer community structure [4].

Lake Engure is the largest basin at the western coastal area of the Gulf of Riga, which has been developed due to processes at several stages of the Baltic Sea evolution. The first basin influencing the area of Lake Engure was the Baltic Ice Lake. The area of the sloping Baltic Ice Lake plain (25-30 to 8-10 $\mathrm{m}$ above sea level), nowadays located between Baltic Ice Lake and the Littorina Sea coastline, is covered throughout by sand and gravel deposits [5] surround the lake's western and southern coasts (Fig. 1). Sandy inland dunes were formed in this area after the regression of the Baltic Ice Lake due to poorly developed vegetation and strong winds.

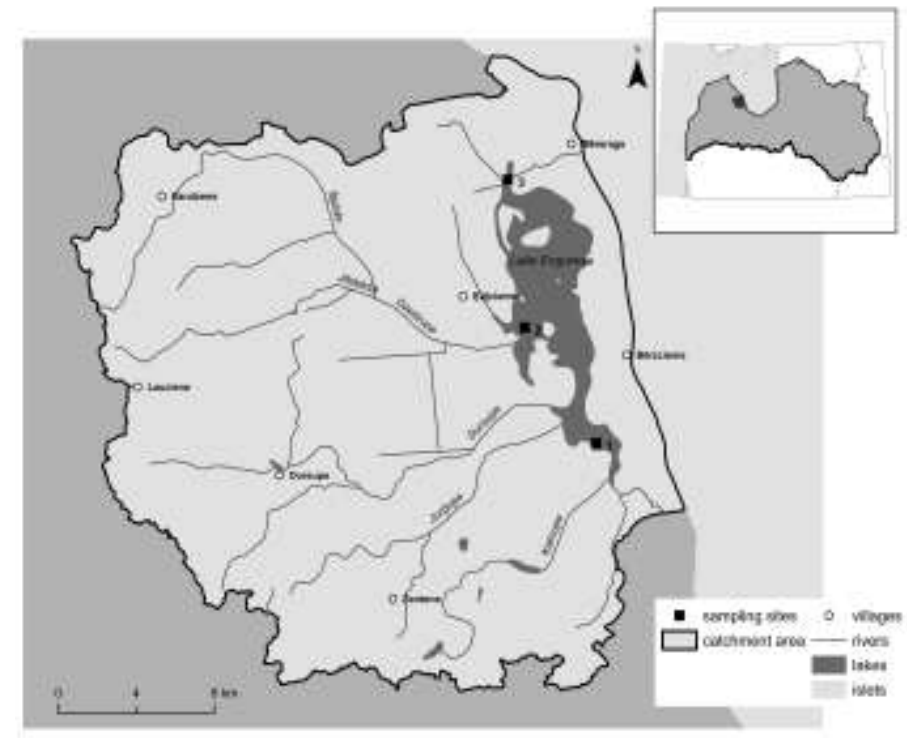

Fig. 1. Location of the study area and lake sediment sampling sites.

Lake Engure and the surrounding areas also have weak traces of sediments accumulated during the Ancylus Lake, the fresh water basin that replaced the Yoldia Sea after the isostatic rise of the south Scandinavian landforms. This can probably be explained by erosion of sediments during the Littorina Sea transgression, when rising oceanic levels broke through the Great Belt. The water level of this brackish basin increased 5-6 $\mathrm{m}$ above the present level in the lake area. The area of the present Lake Engure and the low laying surrounding areas were the lagoon of the Littorina Sea. Later the deepest part of the Littorina Plain was separated from the sea as a result of the Littorina Sea regression, lowering of the water level and became a lake. About a $20 \mathrm{~km}$ long spit consisting of sands and gravel appears between Lake Engure and the Gulf of Riga after the Littorina Sea regression. Initially, it occurred as a large underwater bar, which later appeared above water and was covered by parallel dune ridges, separating the lagoon from the open sea [5], and the basin conditions changed from brackish to freshwater. Nowadays it is a $1.5 \mathrm{~km}$ to $2.5-3 \mathrm{~km}$ wide belt of land separating Lake Engure from the Gulf of Riga (Fig. 1). Lake depression is shallow, with uneven bottom relief, which is covered by sand, silty clay, silt with organic matter and gyttja. The Mērsrags Canal was excavated in 1842, which caused abrupt lake water level decrease by 1.5 to $2 \mathrm{~m}$. As a result, 
areas of land suitable for agriculture appear in the areas earlier covered by lake waters. However, large areas of the flat lake bank slopes became favourable for fen peat formation, but some sandy areas distant from the lake became dry and new dune formation processes take place.

Lake sediments in Latvia have been investigated by geological, paleoecological and paleobotanical methods during the last decades $[6,7,5,8]$. Though these data reveal only basic information about the lake genesis and their development, the obtained results are very important for decision making and the lake management. Nowadays, Lake Engure is surrounded by forest [9], so pollution from human impact probably comes mainly through the air or brings in the inflowing rivers like Dzedrupe, Dursupe, Jurgiupe, Kalnupe, and Melnupe. Paleolimnological, paleobotanical and chemical investigations of lake sediments using instrumental analytical methods can help reveal processes and impacts influencing lake development and human pressures, especially during the last centuries. Analysis of major and trace elements in lake sediments [10, 11], diatom assemblages, phosphorus and organic carbon $[12,13,14]$ are used as an efficient tool to study spatio-temporal changes of sedimentary records.

The aim of this study is to analyse sedimentary records of Lake Engure formed during the last few hundred years and evaluate possibilities to study the character of human impacts from sedimentary records.

\section{MATERIALS AND METHODS}

This study includes analyses of results from field samplings and laboratory analyses. Sediment sampling was carried out in three sites with an aim to get an impression about the lake sediment composition, thickness and accumulation rates. Sediment dating using ${ }^{210} \mathrm{~Pb}$ analysis was done at the Lithuanian Nature Research Centre using known methods [15].

Coring was carried out by using an ordinary gravity corer with Plexiglas tube of $5 \mathrm{~cm}$ in diameter and $100 \mathrm{~cm}$ in length. Sequential loss on ignition (LOI) is a common and widely used method to estimate the organic matter (OM) and carbonate matter (CM) content of sediments [e.g., 16, 17, 18]. The content of $\mathrm{OM}$ and $\mathrm{CM}$ were analyzed by sequentially ashing samples at $5500 \mathrm{C}$ for $4 \mathrm{~h}$ and at $9000 \mathrm{C}$ for $2 \mathrm{~h}$ [18]. The dried and sieved $(<100 \mu \mathrm{m})$ samples $(\sim 1 \mathrm{~g})$ were digested with $50 \% \mathrm{HNO}_{3}$ and $30 \% \mathrm{H}_{2} \mathrm{O}_{2}$ on a hot plate at $70 \pm 5{ }^{\circ} \mathrm{C}$ [19]. Metal concentrations were measured by flame atomic absorption (Perkin Elmer 503). The reliability and accuracy of analytical results were checked using blank and reference (ISE 1998.3-921 [Wageningen Evaluating Programmes for Analytical Laboratories], SLRSS-2 river water, BCSS- coastal marine sediments; Analytical Chemistry Standards NRC, Canada) samples. The results from the analysis of SRM were all within the $95 \%$ confidence level of the SRMs. The average recovery varied from $82 \%$ for $\mathrm{Zn}$ to $99 \%$ for $\mathrm{Cr}$ (mean recovery for nine metals was $93 \%$ ).

\section{RESULTS AND DISCUSSION}

Lake Engure belongs to the transitional, accumulative-type lakes. The thickness of the sediment layer with organic matter accumulated after formation of the lake conditions varies from $1-2 \mathrm{~m}$ to $3 \mathrm{~m}$ in the northern part of the lake due to the uneven relief of the lake depression bottom. The gyttja layer in the largest part of the lake reaches $20-30 \mathrm{~cm}$ and mainly has been formed at the second part of the Holocene climatic optimum.

The sediment composition changes within the last 100 years very much reflect a changing environment in the lake basin and the waterbody itself. At first, these changes might be related to basic components of the lake sediments, such as organic matter (OM) and carbonate content (CM) (Fig. 2). Analysis of organic matter (OM) and carbonates (CM) [estimated as loss on ignition (LOI) values in the upper layers of the sedimentary phases (Fig. 2)] indicate significant differences in the accumulation processes in the lake water body, but, at the same time, these indicate an intensification of accumulation processes within the last decades. A specific feature of Lake Engure is a very high heterogeneity of sedimentation conditions within the lake territory. In the northern part of the lake (station 3) the OM content during the last 50 years is randomly increasing, which is an indication of the intensive, but stable production of organic substances and their sedimentation, although the organic matter sedimentation was less intensive than before 1960. In sediments from the central part of the lake (station 2), the concentration of organic matter increased till 1990, but during the last two decades it is decreasing. In the southern part of the lake, organic matter sedimentation conditions within the last decades have been relatively stable. The content of carbonates has been stable in the northern part of the lake, but both in the southern and central part it has significantly increased during the last 50 years.
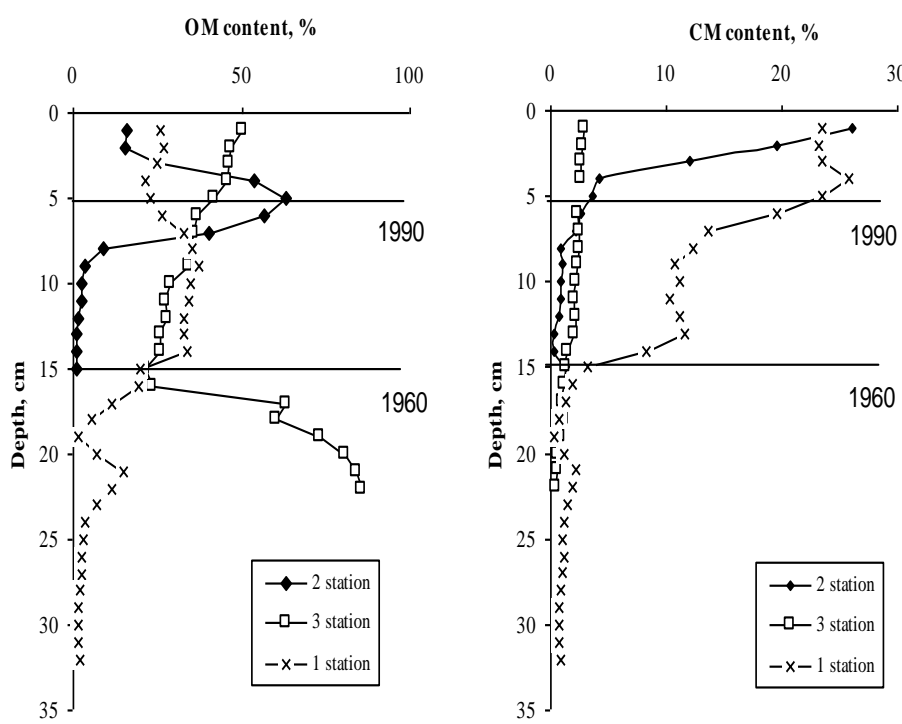

Fig. 2. Concentration of organic matter (OM) and carbonates (CM) (estimated as loss on ignition (LOI) in the upper layers of Lake Engures sediment profiles (sampling sites in the lake body (3 - northern part; 1 - southern part; 2 - central part of the lake). 


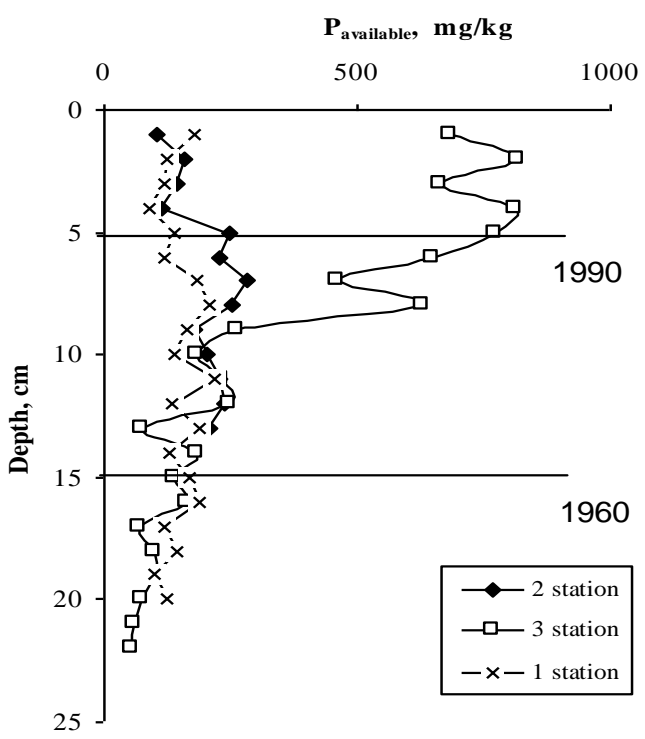

Fig. 3. Concentration of biologically available phosphorous in the upper layers of Lake Engures sediment profiles (sampling sites in the lake body (1 southern part; 2 - central part of the lake; 3 - northern part).

An essential element influencing the development of biota in waterbodies is phosphorous (Fig. 3). Biologically available phosphorus is especially important as it supports eutrophication and the growth of macrophytes in the lake. Phosphorous concentrations in the lake's southern and central parts are slightly increasing, starting from the middle of the $20^{\text {th }}$ century, but after 1990 phosphorus concentrations in these regions of the lake decreased. However, in the northern part of the lake, near the Mērsrags canal, the concentrations during the last 30-40 years increased significantly indicating a major accumulation of phosphorus.
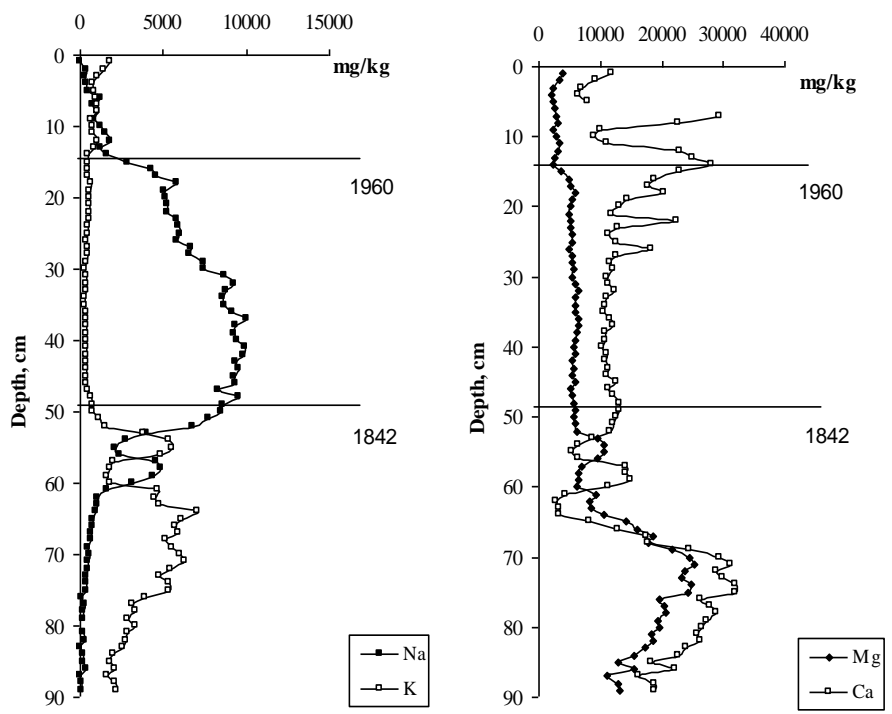

Fig. 4. Concentration of major metals in the Lake Engure sediment profiles (sampling site in the lake body - northern part of the lake).
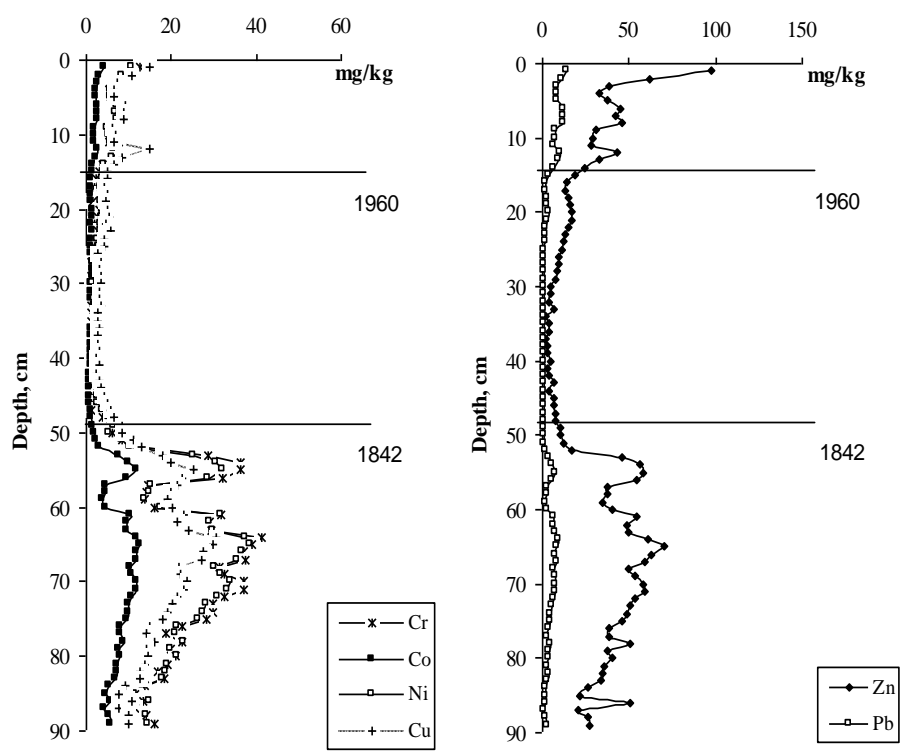

Fig. 5. Concentration of trace elements in the Lake Engure sediment profiles (sampling site in the lake body - northern part of the lake).

To identify changes of major and trace element accumulation character in lake sediments within the last century, a study of the corresponding and dated lake sediment profiles has been done (Fig. 4, 5). In very recent sediments $\mathrm{Na}$ concentrations are relatively lower than $\mathrm{K}$ concentrations, but in older sediments $-\mathrm{K}$ again prevail. Concentrations of $\mathrm{Mg}$ in sedimentary records seem to be little changing during the last centuries (Fig. 4), despite the character of changes from chemical and geological behaviour in the similar element $\mathrm{Ca}$. For both elements relatively high concentrations are common in deeper layers of the sediment profile, but $\mathrm{Ca}$ concentrations also have a significant variability in recent sedimentary profiles, indicating high natural variability of sedimentation conditions and weathering of $\mathrm{Ca}$ containing minerals in the lake basin.

Influences of geochemical processes are evident, if analyzing differences in metal concentrations, especially in case of $\mathrm{Zn}$ and $\mathrm{Pb}$ (Fig. 5). Decrease of concentrations is remarkable for most of the studied trace elements associated with human impacts during the last 50 years. On one hand, this indicates to a low anthropogenic pressure, but, at the same time, indicates how important impacts of naturally ongoing geochemical processes are possibly influencing the elevated element concentrations after building the Mērsrags Canal in 1842. The only element with an increasing tendency of values in sediments within the last 50 years is mercury, which still indicates to recent human impacts.

The Lake Engure sediment composition changes take place at conditions when traditional low-intensity agricultural activities in the lake basin are common (actually the lake basin is relatively sparsely settled and forests and natural meadows dominate). Thus the sedimentary records of their elemental composition can make it possible to follow the changes of human induced and natural loading coming from the lake basin. 
Sediment accumulation conditions were changing during the lake development. This is proved by changes in sediment composition, including chemical parameters. Marine waters flow into the lake through the Mērsrags Canal during the autumn and spring periods. Strong winds promote active mixing of the water layer and probably also influenced the very upper soft sediments, because Lake Engure is very shallow. This was also supported by LOI results, which point to the mixed sediment composition. Lake eutrophication and overgrowing processes started approximately before 5500 calendar years. The lithological composition of sediment profiles show the sand sediment change by sand with organic matter from the bottom part upwards which points to unstable and changing conditions.

Trace and major element changes in Lake Engure sedimentary profiles are influenced by processes happening during the lake development, natural variability of the bedrock in the lake basin, character of land use and human impact in the last centuries. Sedimentation conditions in the lake, as found by the sediment composition analysis of major constituents (carbonates and organic matter) or nutrients, demonstrates significant heterogeneity in sedimentation conditions in different sub-basins of the lake and reduced water flow mobility within the lake water body, due to overgrowth with macrophytes.

Different element groups and their changes in sedimentary profiles demonstrate differing behaviour, largely due to impacts of their sources and processes influencing the element accumulation character. $\mathrm{Na}$ and $\mathrm{K}$ concentrations are influenced by their supply with water inflowing from the lake basin, but $\mathrm{Na}$ concentrations are determined by inflow of brackish waters through the Mērsrags Canal. At the same time, $\mathrm{K}$ as a nutrient is consumed during the vegetation season by macrophytes. As it can be seen in the example of $\mathrm{Na}$ and $\mathrm{K}$ concentration distribution in the sediment profile (Fig. 4), the pattern of $\mathrm{K}$ and $\mathrm{Na}$ concentration changes have an opposite character - when $\mathrm{Na}$ concentrations increase $\mathrm{K}$ concentrations decrease.

Relatively low concentrations of $\mathrm{Na}$ in very recent sediments and higher $\mathrm{K}$ concentrations may indicate the importance of the decay of higher vegetation litter and the release of biogenic $\mathrm{K}$, but, at the same time, impacts of brackish waters from the Gulf of Riga on the sedimentary composition can be considered as relatively low. A major increase of $\mathrm{Na}$ concentrations has been found for sediments from the depth of $30-50 \mathrm{~cm}$, which roughly corresponds to the period after building the Mērsrags Canal in 1842, when, at first, the lake level significantly decreased, but afterwards inflow of brackish waters from the Gulf of Riga occurred. In deeper sediment layers, $\mathrm{K}$ concentration again increases, but $\mathrm{Na}$ concentration decreases. Historically, $\mathrm{K}$ concentrations have been elevated, probably considering the biogenic origin of $\mathrm{K}$ in the aquatic environment

$\mathrm{Ca}$ and $\mathrm{Mg}$ concentrations in sedimentary records differ from those of all other studied elements and seemingly are not much affected by anthropogenic pressures (Fig. 4), as far as elevated concentrations are common for the deepest sedimentary layers, when the intensity of carbonate mineral weathering could be a major factor affecting the pattern of changes of both elements. A significant variability of $\mathrm{Ca}$ concentrations in recent sedimentary profiles probably indicates high natural variability of sedimentation conditions and weathering of $\mathrm{Ca}$ containing minerals in the lake basin. Several studies [e.g., 20, 21] have shown that the primary production of Charophyte beds can influence sediment chemistry, e.g., promote precipitation of calcite. As the cover of Chara is very dense in Lake Engure, calcite precipitation promoted by Chara could be a possible explanation for higher concentrations of calcium in the upper sediment layers.

Concentrations of trace elements like $\mathrm{Pb}, \mathrm{Co}, \mathrm{Ni}, \mathrm{Cu}$ and elements, the presence of which might be associated with human activities (such as $\mathrm{Zn}$ ), may help to identify human caused pollution and help to follow human induced changes in the pollution loading (Fig. 5). However, the present study indicates the low recent increase of these contaminants in the sediments of the Lake Engure.

The results obtained in this study reveal different sedimentation conditions. As Lake Engure is a very shallow lake, the upper part of sediments can be disturbed by waves and bioturbation, therefore the interpretation of results is more difficult than in deeper lakes. This study proves that investigation of such a large shallow basin as Lake Engure is complicated and produces diverse results, due to different sedimentation conditions and local factors.

\section{CONCLUSIONS}

Sediments in the lake depression and surrounding area has been accumulated under conditions of changing basins of the Baltic Sea stages, geological processes, climate and human impact. Different sediment characteristics can be explained by differing sedimentation conditions in a large basin. The excavation of the Mērsrags Canal has caused changes in sedimentation in the entire lake and has even been recorded in the sediment composition. Pollution has been reflected by concentrations of major and trace elements in sediment cores.

The metal concentrations in sediments of lakes in Latvia are at background levels. This may be explained with geochemical factors and the abundance of sedimentary deposits in the drainage basins, as well as a minimal anthropogenic load. At the same time, direct anthropogenic impacts are evident in several places, which are related to influences of point sources and transboundary transport impacts. Analysis of the elemental composition of sediment profiles can provide information about the changes of human induced and natural loading within the lake basin.

\section{REFERENCES}

1. Dearing, J.A., Jones, R.T., Shen, J., et al. Using multiple archives to understand past and present climate-human-environment interactions: the lake Erhai catchment, Yunnan Province China. Journal of Paleolimnology, 2005, vol. 40 No 1, p. 3-31.

2. Saunders K.M., Hodgson D.A., Harrison J., et al. Palaeoecological tools for improving the management of coastal ecosystems: a case study from Lake King (Gippland Lakes) Australia. Journal of Paleolimnology, 2008, vol. 40 No 1, p. 33-47. 
3. Cohen, A. S. Paleolimnology: The History and Evolution of Lake Systems. New York: Oxford University Press, 2003.

4. Waters, M.N. Shallow lake trophic status linked to late Holocene climate and human impacts. Journal of Paleolimnology, 2009, vol. 42, p. 58-62.

5. Eberhards, G., Saltupe, B. Geological history, relief and deposits of the Lake Engures (Engure) area along the Baltic Sea. Proceedings of Latvian Academy of Sciences, Sect. B, 2000. vol. 54, No (5/6), p. 141147.

6. Alksnītis, R. Pārskats par ezeru sapropeḷu atradṇu meklēšanas darbiem Talsu, Tukuma, Kuldīgas, Saldus un Dobeles rajonos. VG̣D Fonds, inv. nr. 11507., 1995.

7. Juškevičs, V., Mūrnieks, A., Misāns, J. 42. lapa - Jūrmala. Latvijas geologískā karte. Valsts geoologijas dienests, Rīga, 1999, 52 lpp.

8. Rumpe, L. Paleoenvironmental changes near Gipka and Lake Engure in the western coast of the Gulf of Riga during the Littorina Sea stage. Department of Quaternary Geology and Physical Geography, Stockholm University. Abstract volume. 2003, p. 15-16.

9. Vīksne, J. The bird lake Engure. Jāṇa sēta, Rīga, 1997.

10. Renberg, I., Bindler, R., Brannvall, M.L. Using the historical atmospheric lead-deposition record as a chronological marker in sediment deposits in Europe. Holocene, 2001, vol. 11 No 5, p. 511-516.

11. Lepane, V., Morriset, M., Viitak, A., et al. Partitioning of metals between operational fractions in the sediment record from Lake Peipsi. Chemical Ecology, 2010, vol. 26, p.35-48.

12. Anderson, N.J., Rippey, B., Gibson, C.E. A comparison of sedimentary and diatom-inferred phosphorus profiles: implications for defining pre-disturbance nutrient conditions. Hydrobiologia, 1993, vol. 253, p. 357.-366.

13. Marchetto, A., Musazzi, S. Comparison between sedimentary and living diatoms in Lago Maggiore (N.Italy): implications of using transfer functions. Journal of Limnology, 2001, vol. 60, No 1, p. 19-26.

14. Rasanen, J., Kentitamies, K., Sandman, O. Paleolimnological assessment of the impact of logging on small boreal lake. Limnologica, 2007, vol. 37, p. 193-207.

15. Schönhofer, F., Wallner, G. Very rapid determination of ${ }^{226} \mathrm{Ra},{ }^{228} \mathrm{Ra}$ and ${ }^{210} \mathrm{~Pb}$ by selective adsorption and liquid scintillation counting, Radioactivity and Radiochemistry, 2001, vol. 12, p. 33-38.

16. Dean, W.E. Jr. Determination of carbonate and organic matter in calcareous sediments and sedimentary rocks by loss on ignition: Comparison with other methods. Journal of Sedimentary Petrology, 1974, vol. 44, p. 242-248.

17. Bengtsson, L., Enell, M. Chemical analysis. In: Handbook of Holocene Palaeoecology and Palaeohydrology. Oxford University Press,Oxford, 1986.

18. Heiri, O., Lotter, A.F., Lemcke, G. Loss on ignition as a method for estimating organic and carbonate content in sediments: reproducibility and comparability of results. Journal of Paleolimnology, 2001, vol. 25, 101-110.

19. Csuros, M., Csuros, C. Environmental Sampling and analysis for metals. Boca Raton : CRC Press, 2002.

20. Kufel, L., Kufel, I. Chara beds acting as nutrient sinks in shallow lakes - a review. Aquatic Botany, 2002, vol. 72, p. 249-260.

21. Pentecost, A., Andrews, J.E., Dennis, P.F., et al. Charophyte growth in small temperate water bodies: Extreme isotopic disequilibrium and implications for the palaeoecology of shallow marl lakes. Palaeo, 2006, vol. 240, p. 389-404.

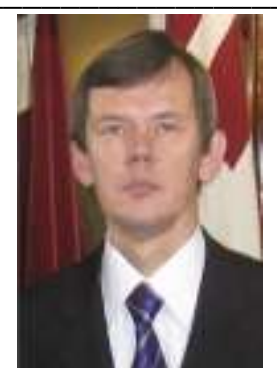

Maris Klavins, Dr.hab.chem., Professor at the University of Latvia, Faculty of Geography and Earth Sciences, Department of Environmental Sciences. M.Kḷaviňš obtained his scientific degree in chemistry of biologically active compounds at the Moscow State University in 1986, but a habilitation degree at the University of Latvia in 1994. He is a member of the Academy of Sciences of Latvia, coordinator of International Humic Substances Research Society (IHSS). Research interests are related to studies of natural organic matter, wetlands and bogs and environmental pollution problems.

Address: University of Latvia, Raiņa bulv. 19, LV-1586, Riga, Latvia E-mail: maris.klavins@lu.lv

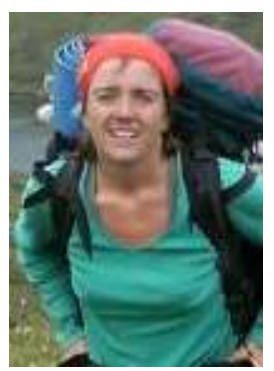

Ilga Kokorite, Dr geogr., Head of the Laboratory of Environmental Quality Monitoring of the University of Latvia, Faculty of Geography and researcher at the Institute of Biology. I.Kokorite obtained her $\mathrm{Ph} . \mathrm{D}$ in geography in 2007. Her research interests are hydrochemistry of Latvian waterbodies.

E-mail: ilga.kokorite@lu.lv

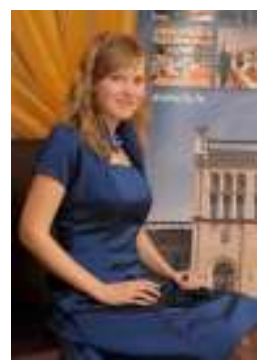

Maruta Jankevica, is a student at the Faculty of Geography ad Earth Sciences. Her research interests are related to phosphorus accumulation in lake sediments.

E-mail: maruta.jankevica@gmail.com

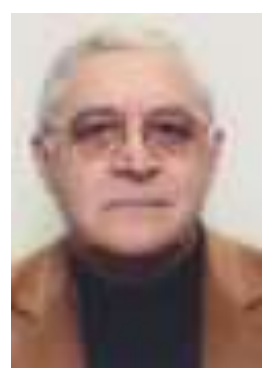

Valerijs Rodinovs, after graduating Leningrad State University Department of Oceanology, has worked as a scientist at the Institute of Biology of the University of Latvia since 1973. His scientific interests cover hydrology, aquatic chemistry of inland waters of Latvia, as well as research in aquatic biology.

E-mail: roval@email.lubi.edu.lv

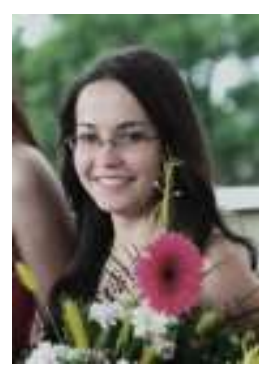

Liga Dreijalte, is a student at the Faculty of Geography ad Earth Sciences. Her research interests are related to accumulation of heavy metals in sediments.

E-mail: liga.dreijalte@gmail.com

Māris Kḷaviṇš, Ilga Kokorīte, Maruta Jankēvica, Valērijs Rodinovs, Līga Dreijalte. Cilvēka saimnieciskās darbības izmaiṇu rekonstrukcija pēdējos 300 gados, izmantojot Engures ezera nogulumu analīzes

Vides piesārņojums ar mikroelementiem tiek uzskatîts par vienu no svarīgākajām vides problēmām. Šì pêtījuma mērkis bija analizēt mikroelementu koncentrāciju no Engures ezera sedimentiem Latvijā un analizēt faktorus, kas ietekmē to pieejamību. Ezera nogulumu slānnu analīžu rezultāti var sniegt vērtīgu informāciju par ezera attīstības gaitu, kā arī dabiskajiem un antropogēnajiem procesiem un to mainību ezeru sateces baseinā. Pētijjuma ietvaros tika ievāktas nogulumu serdes, kas laboratorijā tika sadalītas $1 \mathrm{~cm}$ biezos slānos. Šiem paraugiem tika veikts datējums pēe ${ }^{210} \mathrm{~Pb}$, analizēts organisko vielu, karbonātu un metālu saturs. Engures ezeram raksturīgi ḷoti heterogēni sedimentu uzkrāšanās apstākḷi, ko raksturo atšķirīgs ezera nogulumu slāṇu dziḷums un to fizikāliḳimiskās īpašības, piemēram, nogulumu analīzes liecina, ka ezera dienvidu un centrālajā dą̣ā pie Dzedrupes ietekas pēdējo 100 gadu laikā ir pieaudzis karbonātu saturs, bet pie Mērsraga kanāla to koncentrācija nav būtiski mainījusies. Metālu koncentrācijas Engures ezera nogulumos vêrtējamas kā ḷoti zemas, īpaši, 
salīdzinot ar Rietumeiropas ezeriem. Zemais smago metālu saturs nogulumu augšējos liecina par nelielu antropogēno slodzi, kā arī var norādīt uz dabisku geoķīmisko procesu izmaiṇām ezera sistēmā pēc Mērsraga kanāla izbūves 1842. gadā.

Марис Клявиныш, Илга Кокорите, Марута Янкевица, Валерий Родинов, Лига Дрейялте. Реконструкция хозяйственной деятельности человека за последние 300 лет на основе анализа донных отложений озера Энгуре

Загрязнение окружающей среды микроэлементами является одной из важнейших проблем окружающей среды. Цель этой работы - провести анализ концентраций микроэлементов в осадках озера Энгурес в Латвии и проанализировать факторы, который влияют на них. Анализ донных отложений позволяет получить ценную информацию о развитии озера, а также об изменении природных и антропогенных процессов на водосборе озера. В рамках исследования были отобраны колонки образцов донных отложений разной глубины, которые потом в лаборатории разделены на слои толщиной 1 см. В этих образцах были проведены анализы датирования изотопа $210 \mathrm{~Pb}$, а также анализы органического вещества, концентрации карбонатов и тяжелых металлов. Для озера Энгуре характерны очень неоднородные условия накопления донных отложений, их глубина и физикохимический состав. Например, в составе отложений южной части озера и в центральной, в зоне влияния притока Дзедрупе за последние 100 лет возросло содержание карбонатов, в северной части у канала Мерсрага их концентрации существенно не изменялись за этот период. Концентрации тяжелых металлов в донных отложения озера Энгуре можно оценить как низкие по сравнению, например, с озерами Западной Европы. Такие концентрации тяжелых металлов в верхних слоях донных отложений свидетельствуют о низкой антропогенной нагрузке на водосбор озера и в тоже время указывают на изменения естественных геохимических процессов в озерной экосистеме после прорытия канала Мерсрага в 1842 году. 